\title{
Staphylococcus epidermidis Prevails Staphylococcus aureus in Multispecies Biofilm under Gentamicin Stress
}

\author{
Noor Jabbar Karam ${ }^{1}$, Harith Jabbar Fahad Al-Mathkhury ${ }^{2}$ \\ Department of Biology, College of Science, University of Baghdad, Baghdad, Iraq
}

\begin{abstract}
Out of 60 staphylococcal isolates isolated form different sources, the results revealed that 20 and 10 were identified as $S$. aureus and S. epidermidis, respectively. These results were confirmed by detecting 16sRNA gene. Remarkably, 80\% of S. aureus and 80\% of S. epidrmidis isolates developed Methicillinresistance. Findings of the current work demonstrated that most of methicillin resistant S. aureus (MRSA) and methicillin resistant S. epidermidis (MRSE) formed weak biofilm. The competition between S. aureus and $S$. epidermidis in multispecies biofilm were tested at several conditions encompassed temperature, pH, and starvation. Results showed that the numbers of biofilm cells have intensely decrease to undetectable limits in the presence of Gentamicin, approximately, at all tested conditions. With few exceptions, $S$. epidermidis showed a noticeable dominance in all species combinations.
\end{abstract}

\section{Introduction}

Staphylococci defined as a diverse group of bacteria that cause different types of diseases which could be minor skin infections up to life-threatening bacteraemia. Staphylococci still the major cause of both hospital and community acquired infections worldwide even the high continued efforts to control their spread. Staphylococcus aureus and Staphylococcus epidermidis considered as the two major opportunistic pathogens of this genus [1].

Fifty years ago, Methicillin and different semisynthetic penicillins were commonly used which led to the appearance of Methicillin Resistance Staphylococcus aureus (MRSA) and S. epidermidis (MRSE), and that continue to persevere in both the healthcare and community environments. Currently, the results revealed that $80 \%(16 / 20)$ of $S$. aureus, $80 \%$ (8/10) S. epidrmidis, and 86.6\% (26/30) other CONS isolates developed Methicillinresistance.

Biofilm formation may be determined to detect the capability of staphylococci to colonize the biomedical devices. The microtiter plate (MtP) test devised by Christensen et al. [2].Were most commonly used as the phenotypically methods for slime and/or biofilmproduction.

The organization of the biofilm into complex structures is regulated by the exchange of chemical signals between cells in a process known as quorum sensing. Quorum sensing is a strategy of cell-cell communication benefiting the biofilm community by controlling unnecessary overpopulation and competition for nutrients with important implications for the infectious process [3].

This study was designed to achieve the following aims; 1) studying the competence between isolates (resistant vs sensitive to environmental conditions ( $\mathrm{pH}$, temperature, and starvation). 2) detecting the role of Gentamicin on competition at the same environmental conditions and 3) investigating the competence capacity between the two species in vivo using murine model.

\section{Materials and Methods}

Specimen'scollection

Sixty clinical specimens referring to Flow Catheter, Burn, Indwelling Devices, Midstream Urine, Wounds Swabs, and Sputum, were collected from patients attending several hospitals in Baghdad (AL Karama Hospital, Teaching Laboratories of Medical City) for the period from October 2015 to January 2016.

Isolation and identification ofstaphylococci

All specimens were streaked on mannitol salt agar and Blood Agar. Thereafter, all plates were incubated aerobically for $24 \mathrm{~h}$ at $37^{\circ} \mathrm{C}$. The grown coloines were identified according to Bergey's Manual [4] depending on the morphological features on culture media and biochemical tests[5, 6] as follows:

Detection of MRSA by Cefoxitin Disk Diffusionmethod All the isolates were subjected to cefoxitin disk diffusion test using a $30 \mu \mathrm{g}$ disk. A 0.5 McFarland standard suspension of the isolate was made and lawn culture was done on Mueller-Hinton agar plate. Plates were incubated at $37^{\circ} \mathrm{C}$ for $18 \mathrm{hr}$. and zone diameters were measured. An inhibition zone diameterx of $\leq 19 \mathrm{~mm}$ was reported as Methicillin-resistance and $\geq 20 \mathrm{~mm}$ was considered as methicillin-sensitive $S$. aureues, and an inhibition zone diameter of $\leq 24 \mathrm{~mm}$ was reported as Methicillinresistance and $\geq 25 \mathrm{~mm}$ was considered as methicillinsensitive $S$. epidermidis [7].

Extracting and purifying of genomicDNA

Genomic DNA from all isolates $(n=60)$ was extracted and purified by using Genomic DNA Extraction (Geneaid, USA), using manufacturer protocol, which can be summarized asfollows:

\section{Multiplex PCR}

The presence of 16sRNA for S. aureus. 16sRNA for $S$. epidermidis genes and mecAin both species were detected by amplifying them as described by Arciola et al. [8]. 


\section{International Journal of Science and Research (IJSR) \\ ISSN (Online): 2319-7064}

Index Copernicus Value (2015): 78.96 | Impact Factor (2015): 6.391

mecAand 16sRNA for $S$. aureus and 16sRNA for $S$. epidermidis primers (Table 1) were provided in lyophilized form (Bioneer, Korea), dissolved in DNase free distilled water to give a final concentration of $100 \mathrm{pmol} / \mu \mathrm{l}$ as recommended by provider and stored in a freezer until use.

Table 1: DNA primers used in the present study [8]

\begin{tabular}{|l|l|l|l|}
\hline Id & \multicolumn{1}{|c|}{ Primers } & \multicolumn{1}{|c|}{ Target gene } & \multicolumn{1}{|c|}{$\begin{array}{c}\text { Amplicon } \\
\text { size }(\mathrm{pb})\end{array}$} \\
\hline 1 & $\begin{array}{l}\text { SA1 (5'-AATCTTTGTCGGTACACGATATTCTTC ACG-3') } \\
\text { SA2 (5'-CGT AATGAGATTTCAGTAGAT AATACAACA-3') }\end{array}$ & $\begin{array}{l}\text { 16srRNA of } S . \\
\text { aureus }\end{array}$ & 108 \\
\hline 2 & $\begin{array}{l}\text { SE1 (5'-ATCAAAAAGTTGGCGAACCTTTTC A-3') } \\
\text { SE2 (5'-CAAAAAGAGCGTGGAGAAAAGT ATCA-3') }\end{array}$ & $\begin{array}{l}\text { 16srRNA of } S . \\
\text { epidermidis }\end{array}$ & 124 \\
\hline 3 & $\begin{array}{l}\text { MRS1 (5'-TAG AAA TGACTGAACGTCCG-3') } \\
\text { MRS2 (5'-TTG CGA TCAATGTTACCGTAG-3') }\end{array}$ & mecA & 154 \\
\hline
\end{tabular}

PCR mixture was set up in a total volume of $20 \mu$ included $2 \mu \mathrm{l}$ of each primer $(10$ micromole/ $\mu \mathrm{l})$ and $6 \mu \mathrm{l}$ of template DNA $(50 \mathrm{ng} / \mu \mathrm{l})$ have been used. The rest volume was completed with free nuclease water. Negative control contained all material except DNA, in which D.W. was added instead of template DNA. Program of DNA amplification was as follows: initial denaturation at $92^{\circ} \mathrm{C}$ for 3 min., 30 cycle at $92^{\circ} \mathrm{C}$ for 1 min., $56^{\circ} \mathrm{C}$ for 1 min., $72^{\circ} \mathrm{C}$ for $1 \mathrm{~min}$. and a final extension at $72^{\circ} \mathrm{C}$ for $3 \mathrm{~min}$.

\section{Determination of Gentamicin minimal inhibitory concentration (MIC).}

Depending on microdilution method described by CLSI[9], different concentrations of Gentamicin $(2-1024 \mu \mathrm{g} / \mathrm{ml})$ were dissolved in Mueller-Hinton broth. The microtiter plate was incubated overnight at $37^{\circ} \mathrm{C}$. Thereafter, the lowest concentration that inhibits bacterial growth was considered as the MIC.

\section{Biofilm formationassay}

Quantification of biofilm formation by $S$. aureus and $S$. epidermides on abiotic surfaces was assessed as previously described by Nakao et al.[10]. In brief; The wells of sterile 96-well U shaped-bottomed polystyrene microplates were filled with $200 \mu \mathrm{l}$ of an overnight nutrient broth (bacterial concentration was adjusted to be equivalent to McFarland standard no. 0.5) before the plates were covered and incubated aerobically at $37^{\circ} \mathrm{C}$ for $24 \mathrm{~h}$. Each bacterial isolate was tested in triplicate. Control wells were performed by adding bacteria-free nutrient broth. To visualize biofilms, the contents of the wells were aspirated and the wells washed three times with distilledwater to remove loosely adherent cells. The remaining attached bacteria were fixed with $200 \mu \mathrm{l}$ methanol for $30 \mathrm{~min}$. After drying in air, the wells were stained with $200 \mu 10.1 \%$ crystal violet solution for $20 \mathrm{~min}$ at room temperature. Excess stain was rinsed off by placing the plate under running tap water. Thereafter, the plates were dried in a $37^{\circ} \mathrm{C}$ incubator for approximately 30 min to ensure they were completely dry. Subsequently, the adherent cells were resolubilized with $200 \mu \mathrm{l}$ absolute ethanol for 10 minute. Finally, the optical density of each well was obtained at $630 \mathrm{~nm}$ using microplate reader.

Classification summarized in Table 2 based on $\mathrm{OD}_{630}$ values obtained for individual isolate of Staphylococcus spp. were used for the purpose of data simplification andcalculation [11].
Table 2: Classification of bacterial adherence by tissue culture plate method [11]

\begin{tabular}{|c|c|}
\hline Mean OD 630 & Adherence Biofilm Formation \\
\hline $\mathrm{OD} \leq \mathrm{ODc}$ & Non - adherent \\
\hline ODc $<$ OD $\leq 2 *$ ODc & Weakly adherent \\
\hline $2 *$ ODc $<$ OD $\leq 4 *$ ODc & Moderately adherent \\
\hline $4 *$ ODc $<$ OD & Strongly adherent \\
\hline
\end{tabular}

ODc $=$ average OD of negative control $+(3 *$ SD of negative control)

After calculating the biofilm formation capacity for all tested isolates and negative controls, the cut- off value (ODc) was established. It is defined as a three standard deviations (SD) above the mean $\mathrm{OD}$ of the negative control: ODc value was calculated for each microtiter plate separately. When a negative value was obtained, it presented as zero, while any positive value was an indicator for biofilmproduction.

\section{Competition experiments}

\section{Bacterial preparation}

MRSA, MRSE, methicillin sensitive S. aureus (MSSA), and methicillin sensitive $S$. epidermidis (MSSE) cells were diluted to the desired concentration $\left(1.5 \times 10^{8} \mathrm{CFU} / \mathrm{ml}\right)$ and validated by dilution plating in mannitol salt agar. Thereafter, equal volumes of each bacterial isolate in accordance to the following combinations were prepared: A) MRSA and MRSE. B) MRSA and MSSE. C) MSSA and MRSE. and D) MSSA and MSSE.

The aforementioned protocol for biofilm formation assay was adopted to form biofilm for each previously mentioned combination. However, Different $\mathrm{pH}$ values $(6,7$, and 8), incubation temperature $\left(10,37\right.$, and $\left.45^{\circ} \mathrm{C}\right)$ and starvation (culture medium was diluted 1:100 and 1:1000 with D. W.). Viable count was accomplished for each assay prior and post Gentamicin addition.

\section{Statistical analysis}

Means were compared to each other via ANOVA and T test. Differences were considered significant when $\mathrm{P} \leq 0.05$.

\section{Results and Discussion}

\section{Bacterial isolation andidentification}

In accordance to biochemical, morphological, and cultural as well as 16sRNA,20 coagulase producers and mannitol fermenters were identified as S. aureus; whereas the other 40

\section{Volume 6 Issue 7, July 2017 www.ijsr.net}




\section{International Journal of Science and Research (IJSR) \\ ISSN (Online): 2319-7064 \\ Index Copernicus Value (2015): 78.96 | Impact Factor (2015): 6.391}

non-mannitol fermenters, non-hemolytic (gamma haemolysis), and coagulase negative were comprised as $S$. epidermidis $(\mathrm{n}=10)$ and otherStaphylococcus species $(\mathrm{n}=30)$.

Numerous studies have investigated the isolation of staphylococci from diverse clinical specimens. Onanuga and Temedie [12]stated that nearly $33.3 \%$ of $S$. aureus isolates were isolated from 120 nares swabs. Babakir-Mina et al. [13] reported that S. aureus was isolated from $22 \%$ of patients attending Sulaimania burn hospital, and formed about $36 \%$ from burn specimens. In another workcarried out byVaez et al. [14]recorded nearly 30.8\%, 26.5\%, $22.7 \%$, 10.8 and $9.2 \%$ of $S$. aureus isolates were isolated from urine, wound, blood, sputum, and abscess, respectively.

Concerning S. epidermidis,Eftekhar and Mirmohamadi[15] reported that $40 \%$ of isolates were isolated form blood; while $14 \%$ of isolates were recovered from urine specimens and another $14 \%$ from wound specimens. Nevertheless, similar percentages $(8 \%)$ were recorded from intravascular catherter and exudate, and other unknown sources (16\%). On the contrary, a study conducted byDiemond-Hernandez et al. [16], showed that $79.5 \%$ of S. aureus and $73.77 \%$ of CONS were detected in different sources.

LikewiseGad et al. [17] found that out of 292 bacterial isolates collected from urine and catheterspecimens, $S$. aureus and $S$. epidermidis represented 6.2\%, 12\%, respectively.

Whilst,Adesida et al. [18] reported that $14.0 \%$ S. aureus nasal colonization in medical students in Lagos,Nigeria. Chopra et al. [19] found that S. aureus comprised 31.11\%; while CONS covered $13.33 \%$. In spite of that, Rabelo et al. [20] collected 404 samples of 202 health professionals, in which $14.6 \%$ (59/404) were S. aureus isolates and 6.2\% (25/404) were classified as $S$. epidermidis; while Onanuga and Onalapo[21]andAl-Geobory[22] declared that about $36 \%$ of 150 urine sample was identified as $S$. aureus. Pant and Rai's [23] findings revealed higher $S$. aureus nasal colonization rate $(43.8 \%)$ in staffs of teaching hospital in Nepal.

These variations may be attributed to the characteristics of the population under study. A population with medication with antibiotics as at the time of sampling may yield a much lower prevalence of $S$. aureus while a population deal with hospital settings may yield a much higher prevalence because of the high number of infectious patients in that environment.

\section{Detection of methicillin resistance}

Cefoxitin $(30 \mu \mathrm{g} / \mathrm{disk})$ disk diffusion method was adopted to investigate the methicillin resistance to all staphylococcal isolates $(n=60)$. Markedly, variable methicillin resistance was noticed among Staphylococcus sp. The results revealed that $80 \%(16 / 20)$ of $S$. aureus, $80 \%$ (8/10) S. epidrmidis, and $86.6 \%(26 / 30)$ other CONS isolates developed Methicillinresistance.

Infections because of MRSA are globallyexpanding problematic issue either inside or outside clinical settings.
Therefore, it is very important for laboratories at epidemiological and clinical levels to distinguish MRSA from MSSA. The reason lying behind such distinguishing in not limited to picking suitable and efficient antibiotic treatment policy for the individual patient, but correspondingly to keepthe transmission of MRSA under control[24].

It has been reported in literature that the results of cefoxitin disk diffusion methodis highly compatible with PCR technique that detect the presence of mecA more than do the results of oxacillin disk diffusion method. Given that, the specificity and sensitivity for detecting methicillin resistance for both methods (Ca. cefoxitin disk and PCR) are 100\% [7, $25,26]$.

Resistance to methicillin in Staphylococcus sp. is primarily mediated by the presence of penicillin-binding protein $2 \mathrm{a}$, encoded by the mecA gene. In certain MRSA strains, the $m e c A$ gene is heterogeneously expressed in vitro[27].

A lot of local studies dealt with MRSA isolation. Among them a study done byAl-Hasani[28]demonstrated that $41 / 49$ $(83.7 \%)$ were MRSA and 30/37 (81\%) were identified as Methicillin resistance coagulase negative staphylococci (MRCONS). Another local study reported that MRSE covered84\%[29]. Likewise,Babakir-Mina et al.[13]stated that among $S$. aureus positive cases, $88 \%$ were MRSA. Upon the results ofAl-Dahbi and Al-Mathkhury [30] MRSA constitutes about 94.3\% among $S$. aureusisolates.Muhammad[31] revealed that $68 \%$ (49/72), 93\% (26/28), and 92\% (34/37) of S. aureus, S. epidrmidis, and other CONS isolates developed Methicillinresistance.

Studies in Iran also paid attention to MRSA isolation, it has been noticed that the incidence MRSAin burn patients was ranging between $60 \%$ - $80 \%$ [32, 33,34]. Similarly, in Isfahan, Iran, Khorvash [35] demonstrated that the prevalence of MRSA in nosocomial infections reached67.2\%. Diverse epidemiological factors like geographical location, health system proficiency in administrating infection control programshave crucial role in such noticed variability of MRSA prevalence. MRSA isolates were mostly isolated form wound infections (43\%). For instant, [36]) reported that MRSA covered around 33\% in a burn center in USA[36].

The results of Al-Hasani [37] (using Methicillin disks $(5 \mu \mathrm{g} / \mathrm{disk})$ revealed that from all 49 isolates, 41 isolates $(83.7 \%)$ showed resistant to the Methicillin while 5 isolates $(10.2 \%)$ were sensitive to the Methicillin and only 3 isolates $(6.1 \%)$ were intermediate resistance. A study carried out byAl-Maliki[38] who showed that the rate of MRSA was $80.3 \%$ and the Methicillin sensitive S. aureus was $16.4 \%$ while the intermediate resistance covered $3.3 \%$. Additionally the same author demonstrated that the rate of MRSE was $86.6 \%$ and the Methicillin sensitive S. epidermidis was $4.4 \%$ and $S$. epidermidis that intermediate resistance to the Methicillin was $8.8 \%$.

When this study compared with the present study two important findings could be observed; the first one is the emergence increased in the Methicillin resistance

\section{Volume 6 Issue 7, July 2017 www.ijsr.net}




\section{International Journal of Science and Research (IJSR) \\ ISSN (Online): 2319-7064}

Index Copernicus Value (2015): 78.96 | Impact Factor (2015): 6.391

staphylococci (both COPS and CONS) strains and decreased of sensitive strains in the very short period of time in our country (Iraq). Additionally, this finding is agreed with many other studies and reports in the world that suggested over the last few decades, there has been an enormous increase and emergence in the prevalence of Methicillin resistance both COPS and CONS strains all over the world and such strains are prone to cause serious outbreaks [39, 40,41]. For instance; CA-MRSA infections have been reported in North America, Europe, Australia, New Zealand, United States and South Korea [42, 43].

The second important finding concluded from the present results, is that the rate of coagulase-negative staphylococci isolates that resistant to Methicillin were higher than the rate of Methicillin resistance coagulase-positive and this finding is agreed with many other studies that mention that $S$. epidermidis is more often resistant to antimicrobial drugs than $S$. aureus and resistance to Methicillin occurs in about $35 \%$ of $S$. aureus while occurs in approximately $75 \%$ of $S$. epidermidis isolates [44, 45]. Some studies mention that $90 \%$ of coagulase-negative staphylococci, mostly $S$. epidermidis, being Methicillin resistant [46, 47].

The variations are due to differences of local conditions, such as climate or microbial prevalence, but others are likely to be caused by differing prevention protocols, topical and systemic treatment of burn wounds, sampling regimens as well as study lengths [48].

Methicillin resistance of $S$. aureus remains to be a significant problem. Rapid and accurate determination of Methicillin resistance is vital for the establishment of successful treatment policy. Misdiagnosing this resistance leads to treatment failures and spread of infections with these resistant strains. This means that disk diffusion testing by using cefoxitin disk is far superior to most of the currently recommended phenotypic methods and is now an accepted method for the determination of MRSA by many authors and related centers including CLSI [49].

\section{Estimation of Minimal Inhibitory Concentration(MIC)}

This estimation was performed for four isolates, two S. aureus (MRSA and MSSA) isolates and two S. epidermidis (MRSE and MSSE) isolates. Different concentrations of Gentamicin $(2-1024 \mu \mathrm{g} / \mathrm{ml})$ were used, the break point of Gentamicin is $\geq 4 \mu \mathrm{g} / \mathrm{ml}$ depending on CLSI[7].

Findings of this work revealed that all isolates were Gentamicin resistance $(\geq 64 \mu \mathrm{g} / \mathrm{ml})$, hence sub-MIC (32 $\mu \mathrm{g} / \mathrm{ml}$ ) was used for further experiments.

\section{Biofilmassay}

The ability of $S$. aureus, S.epidermidis and other staphylococcus spp.biofilm producing isolates were evaluated using pre-sterilized 96 -well polystyrene microtiter plates. In order to estimate biofilm degree, absorbance was determined at $630 \mathrm{~nm}$ by an aid of microtiter plate reader. Given that, absorbance values represented the degree of the biofilm thickness that formed by the studied isolates on the surface of the microtiter well. Obtained results were categorized into four groups based on limits summarized in Table 3.
Table 3: Biofilm degree based on estimated cut off value* of this study

\begin{tabular}{|c|l|l|}
\hline Id & Biofilm degree & OD $_{630}$ limits \\
\hline 1 & Non adherent & $<0.043$ \\
\hline 2 & Weak adherent & $0.043-0.086$ \\
\hline 3 & Moderate adherent & $0.086-0.17$ \\
\hline 4 & Strong adherent & $\geq 0.17$ \\
\hline
\end{tabular}

$*$ cut off value $=$ Mean of controlOD $630+3 *$ Standard deviation $=0.036+3 * 0.0025=0.043$

Regarding limits stated in Table 3, results of the present study revealed that out of 16 MRSA, 12 formed weak biofilm while 4 isolates formed mild biofilm. However, 2 MSSA produced weak biofilm and another two formed mild biofilm. Concerning $S$. epidermidis, two MRSE isolates formed weak biofilm; while six and two MSSE formed weak and mild biofilms, respectively. In regard to MRCONS, seven isolates formed weak biofilm and another seven also made mild biofilm. Additionally, one MSCONS formed mild biofilm. Noticeably, 11 MRCONS isolates and one MSCONS were unable to form biofilm. Nevertheless, no isolate has the ability to produce strong biofilm Table 4 .

Table 4: Biofilm forming degree of $S$. aureus, $S$. epidermidis and other CONS*

\begin{tabular}{|c|c|c|c|c|c|c|}
\hline Id & Isolate sp. & Methicillin & \multicolumn{4}{|c|}{ Biofilm degree } \\
\cline { 3 - 7 } & & & $\begin{array}{c}\text { No } \\
\text { Biofilm }\end{array}$ & $\begin{array}{c}\text { Weak } \\
\text { Biofilm }\end{array}$ & $\begin{array}{c}\text { Mild } \\
\text { Biofilm }\end{array}$ & $\begin{array}{c}\text { Strong } \\
\text { Biofilm }\end{array}$ \\
\hline \multirow{2}{*}{1.} & S. aureus & MRSA & 0 & 12 & 4 & 0 \\
\cline { 3 - 7 } & MSSA & 0 & 2 & 2 & 0 \\
\hline \multirow{2}{*}{2.} & $\begin{array}{c}\text { S. } \\
\text { epidermidis }\end{array}$ & MRSE & 0 & 2 & 0 & 0 \\
\cline { 3 - 7 } 3 & MSSE & 0 & 6 & 2 & 0 \\
\hline \multirow{2}{*}{$\begin{array}{c}\text { Other } \\
\text { CONS }\end{array}$} & MRCONS & 11 & 7 & 7 & 0 \\
\cline { 3 - 7 } & MSCONS & 1 & 0 & 4 & 0 \\
\hline \multicolumn{3}{|c|}{ Total } & 12 & 29 & 19 & ZERO \\
\hline
\end{tabular}

*CONS; coagulase negative staphylococci

A study performed by Muhammad [31] showed that $100 \%$ MRSA isolates were able to form weak biofilm; whereas, MRSE isolates couldn't develop strong biofilm. Nevertheless, $96 \%$ and $4 \%$ of MRSE isolates formed weak and moderate biofilm, respectively.

In the study of Al-Dahbi [50], the biofilm-forming ability of $S$. aureus was evaluated for all isolates (106 isolates) by microtiter plates and the result revealed that $31 \%, 45 \%$, and $22 \%$ of isolates were weakmild, and strong producers, respectively. Noticeably, $2 \%$ of the tested isolates were highly-strong producers.

Gad et al. [17] reported that the biofilm producing in both $S$. aureus and $S$. epidermidis produce high, moderate and weak biofilm for S. aureus $(66.7 \%, 16.7 \%$, and $16.7 \%$, respectively) and $S$. epidermidis $(51.4 \%, 37.1 \%$, and $11.4 \%$,respectively).

The findings of this study was incompatible with a study achieved byGad et al. [51], that they stated the biofilm production assessed by microtiter plates MtP revealed 30 $(90.9 \%)$ strains of $S$. aureus were biofilm positive and 19 strains $(95 \%)$ of CONS were biofilm former. Quantitative biofilm production demonstrated that $22(76.7 \%)$ of strains 


\section{International Journal of Science and Research (IJSR) \\ ISSN (Online): 2319-7064}

Index Copernicus Value (2015): 78.96 | Impact Factor (2015): 6.391

were strong biofilm producers, $8(24.2 \%)$ strains were moderate biofilm producer, and $3(9.1 \%)$ strains were nonbiofilm producers. In CONS, $13(65 \%)$ strains were strong biofilm producers, $6(30 \%)$ moderate biofilm producers and one $(5 \%)$ strain was non-biofilm producer.

Liduma et al.[52] suggested that the percentage of the biofilm producing strains was $47.6 \%$. It is very close to the results that what was observed byArciola et al. [8], who revealed that $46 \%$ of isolates were biofilm producers. Furthermore, in a study of Oliveira and Cunha [53] among 100 isolates studied, $35(35 \%)$ of them were classified as weakly adherent and $46 \quad(46 \%)$ as strongly adherent,foratotalof81(81\%)positiveisolatesand19(19\%)ne gative isolates.

\section{Detection of mecA gene and16sRNA for $S$. aureus and 16sRNA for S.epidermidis}

Results depicted in Figure 1revealed that 20 isolates of $S$. aureus and 10 isolates of $S$. epidermidis were confirmed by 16srRNA amplification. Nearly $80 \%(16 / 20)$ of $S$. aureus isolates, $80 \%$ (8/10)of S. epidermidis, and $86.6 \%$ (26/30) of other CONS isolates were mecA positive. Noticeably, the result of PCR completely matched those resulted from cefoxitin disk diffusion method.

Most of staphylococcal isolates $(83.3 \%)$ of the present study appeared to be resistant to cefoxitin (alternative to methicillin). Such findings are in agreement withFey et al. [54] who stated that $81 \%$ of $S$. aureus were MRSA, whileAl-Geobory[22] found that $90.9 \%$ of $S$. aureus isolates were resistant to methicillin. Additionally,Jain et al. [55] observed about $75.3 \%$ of isolates were methicillin resistant. Yet, these observed differences might be due to the variation in the geographic area, sources of clinical specimens, genetic background and the collection site of isolates. The reason behind continuous increasing in resistant to $\beta$-lactam antibiotics is caused by the overuse or misuse of these antibiotics and by the use of poor quality antibiotics. It also results from natural genetic changes, or mutations, within the organisms that cause diseases.

Bockstael and van Aerschot [56] have been describe four major mechanisms of resistance; Target site alterations, such as changes to the penicillin-binding protein, are common, inactivation of antimicrobials, as by penicillinases or the new carbapenemases, is often seen, Prevention of antimicrobial access to their targets by changing the cell wall permeability that denies access to antimicrobials during the course of therapy and Finally, newly described efflux mechanisms pump the antimicrobial out of the cell before it can reach its target site.

Nevertheless, several studies have shown that resistance in bacteria also acquired by a mutation and acquisition. Acquisition may be passed vertically by selection to daughter cells or horizontally by transfer of resistance genes between strains and species. Exchange of genes is possible by transformation, transduction or conjugation [57].

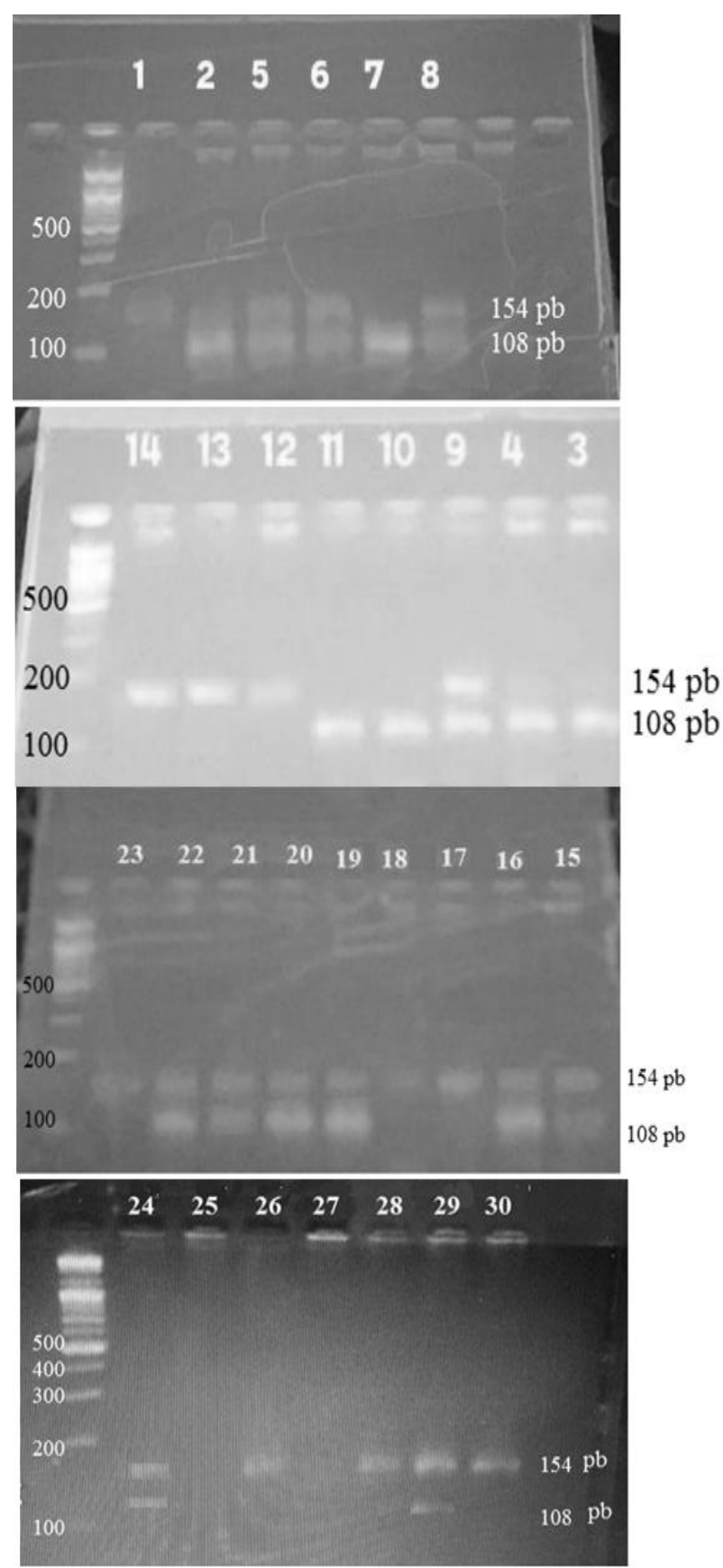




\section{International Journal of Science and Research (IJSR) \\ ISSN (Online): 2319-7064}

Index Copernicus Value (2015): 78.96 | Impact Factor (2015): 6.391
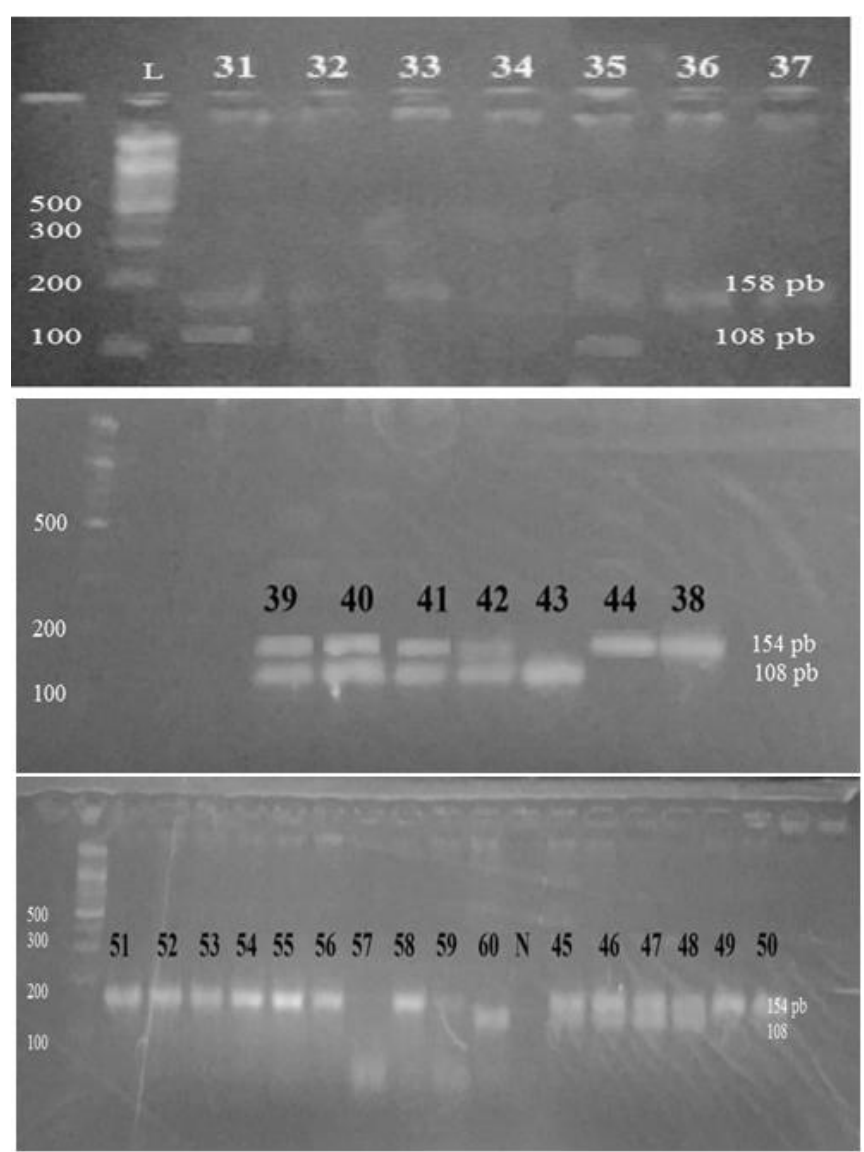

Figure 1: Agarose gel electrophoresis analysis of $m e c A$ gene (154bp) and 16sRNA for S. aureus (108bp) and 16sRNA for

S. epidermidis (124bp). Ladder denotes to $100 \mathrm{pb}$ DNA ladder. Detection was accomplished on agarose gel $(2.5 \%)$ at

$75 \mathrm{~V}$ for 1.5 hour, stained with ethidium bromide and visualized on a UV transilluminator documentation system.

\section{Competition experiments}

Given that the numbers of biofilm cells have dramatically decrease to undetectable limits nearly at all tested conditions (Tables 5 to 11), it can be concluded that Gentamicin has a significant $(\mathrm{P}<0.05)$ impact on viability of cells inside the biofilm. In general, $S$. epidermidis showed a noticeable dominance $(\mathrm{P}<0.05)$ in all species combinations at all tested conditions.

Table 5: Effect of Gentamicin* on Biofilm cell viability at $\mathrm{pH} 7$ and $10^{\circ} \mathrm{C}$

\begin{tabular}{|c|c|c|c|c|}
\hline \multirow{2}{*}{$\begin{array}{c}\text { Species } \\
\text { combinations }\end{array}$} & $\begin{array}{c}\text { Without Gentamicin } \\
(\times \mathbf{1 0} \text { CFU/ml })\end{array}$ & \multicolumn{2}{|c|}{$\begin{array}{c}\text { With Gentamicin } \\
(\times \mathbf{1 0} \text { CFU/ml })\end{array}$} \\
\cline { 2 - 5 } & $\begin{array}{c}\text { S. } \\
\text { aureus }\end{array}$ & $\begin{array}{c}\text { S. } \\
\text { epidermidis }\end{array}$ & $\begin{array}{c}\text { S. } \\
\text { aureus }\end{array}$ & $\begin{array}{c}\text { S. } \\
\text { epidermidis }\end{array}$ \\
\hline MRSA and MRSE & $\mathbf{9 8 4}$ & $\mathbf{1 2 4 0 6}$ & Undetectable & Undetectable \\
\hline MRSA and MSSE & $\mathbf{3 0}$ & $\mathbf{1 8 1}$ & Undetectable & Undetectable \\
\hline MSSA and MRSE & $\mathbf{6 3}$ & $\mathbf{1 2 3}$ & Undetectable & Undetectable \\
\hline MSSA and MSSE & $\mathbf{4 2}$ & $\mathbf{1 2 9 4}$ & Undetectable & Undetectable \\
\hline
\end{tabular}

\section{*Gentamicin was added $32 \mu \mathrm{g} / \mathrm{ml}$ (subMIC)}

Markedly, biofilm degree was highlyaffected $(\mathrm{P} \leq 0.05)$ by Gentamicin (Figure 2).

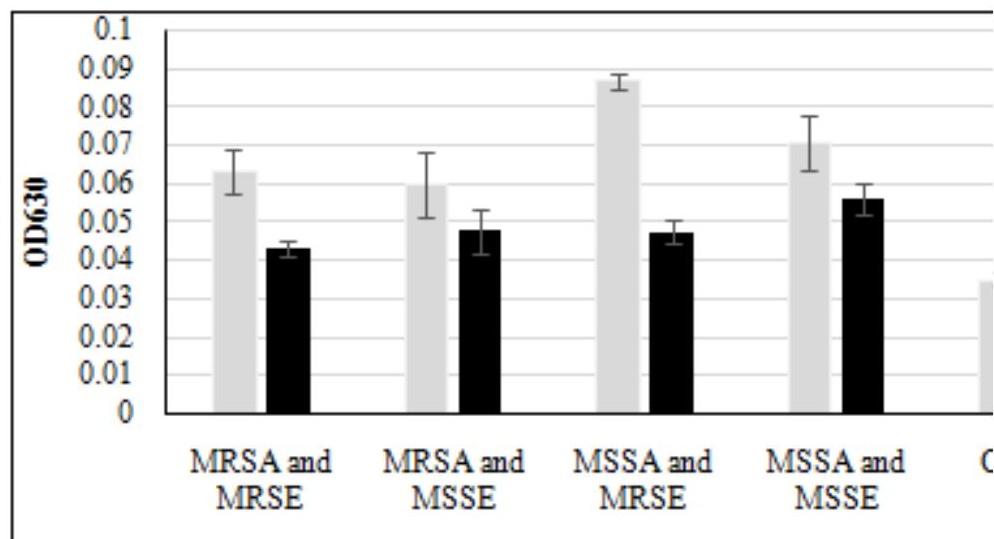

Figure 2: Effect of Gentamicin $(32 \mu \mathrm{g} / \mathrm{ml})$ on Biofilm at $\mathrm{pH}$ 7 and $10^{\circ} \mathrm{C}$

Nevertheless, at $37^{\circ} \mathrm{C}$, MRSA and MSSA outnumbered MRSE and MSSE, respectively (Tables 6). However, Gentamicin has decreased the biofilm thickness $(P \leq 0.05)$ in exception for MRSA and MSSE coexistence, in which biofilm thickness increased insignificantly $(P \geq 0.05)$ as it is depicted in Figure 3.

Table 6: Effect of Gentamicin* on Biofilm cell viability at $\mathrm{pH} 7$ and $37^{\circ} \mathrm{C}$

\begin{tabular}{|c|c|c|c|c|}
\hline \multirow{2}{*}{ Species combinations } & \multicolumn{2}{|c|}{ Without Gentamicin $(\times \mathbf{1 0}$ CFU/ml $)$} & \multicolumn{2}{|c|}{ With Gentamicin $(\times$ 10 CFU/ml $)$} \\
\cline { 2 - 5 } & S. aureus & S. epidermidis & S. aureus & S. epidermidis \\
\hline MRSA and MRSE & $\mathbf{2 0 1 5}$ & $\mathbf{8 8 5}$ & Undetectable & Undetectable \\
\hline MRSA and MSSE & $\mathbf{5 6 5}$ & $\mathbf{1 0 1 8}$ & Undetectable & Undetectable \\
\hline MSSA and MRSE & $\mathbf{2 5 7 2 4}$ & $\mathbf{2 8 6 8}$ & Undetectable & Undetectable \\
\hline MSSA and MSSE & $\mathbf{5 7 1}$ & $\mathbf{8 0 5}$ & Undetectable & Undetectable \\
\hline
\end{tabular}

*Gentamicin was added $32 \mu \mathrm{g} / \mathrm{ml}$ (subMIC) 


\section{International Journal of Science and Research (IJSR) \\ ISSN (Online): 2319-7064}

Index Copernicus Value (2015): 78.96 | Impact Factor (2015): 6.391

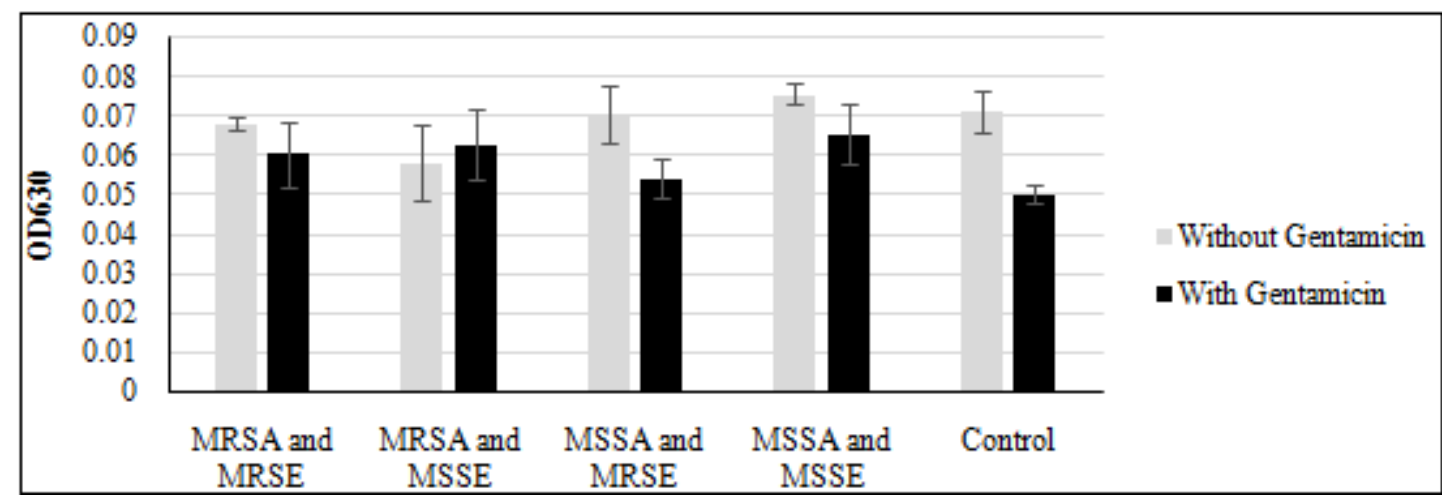

Figure 3: Effect of Gentamicin $(32 \mu \mathrm{g} / \mathrm{ml})$ on Biofilm at $\mathrm{pH} 7$ and $37^{\circ} \mathrm{C}$

At $45^{\circ} \mathrm{C}$, a marked dominance of $S$. epidermidis over $S$. aureus was noticed (Table 7). Moreover, biofilm thickness was affected $(\mathrm{P} \leq 0.05)$ by the presence of Gentamicin as it depicted in Figure 4.

Table 7: Effect of Gentamicin* on Biofilm cell viability at $\mathrm{pH} 7$ and $45^{\circ} \mathrm{C}$

\begin{tabular}{|c|c|c|l|l|}
\hline \multirow{2}{*}{ Species combinations } & \multicolumn{2}{|l|}{ Without Gentamicin $(\times \mathbf{1 0}$ CFU/ml } & \multicolumn{3}{|l|}{ With Gentamicin $(\times \mathbf{1 0}$ CFU/ml $)$} \\
\cline { 2 - 5 } & S. aureus & S. epidermidis & S. aureus & S. epidermidis \\
\hline MRSA and MRSE & $\mathbf{2 0}$ & $\mathbf{3 1}$ & Undetectable & Undetectable \\
\hline MRSA and MSSE & $\mathbf{2 4}$ & $\mathbf{3 4}$ & Undetectable & Undetectable \\
\hline MSSA and MRSE & $\mathbf{3 1}$ & $\mathbf{3 9}$ & Undetectable & Undetectable \\
\hline MSSA and MSSE & $\mathbf{1 9}$ & $\mathbf{2 8}$ & Undetectable & Undetectable \\
\hline
\end{tabular}

*Gentamicin was added $32 \mu \mathrm{g} / \mathrm{ml}$ (subMIC)

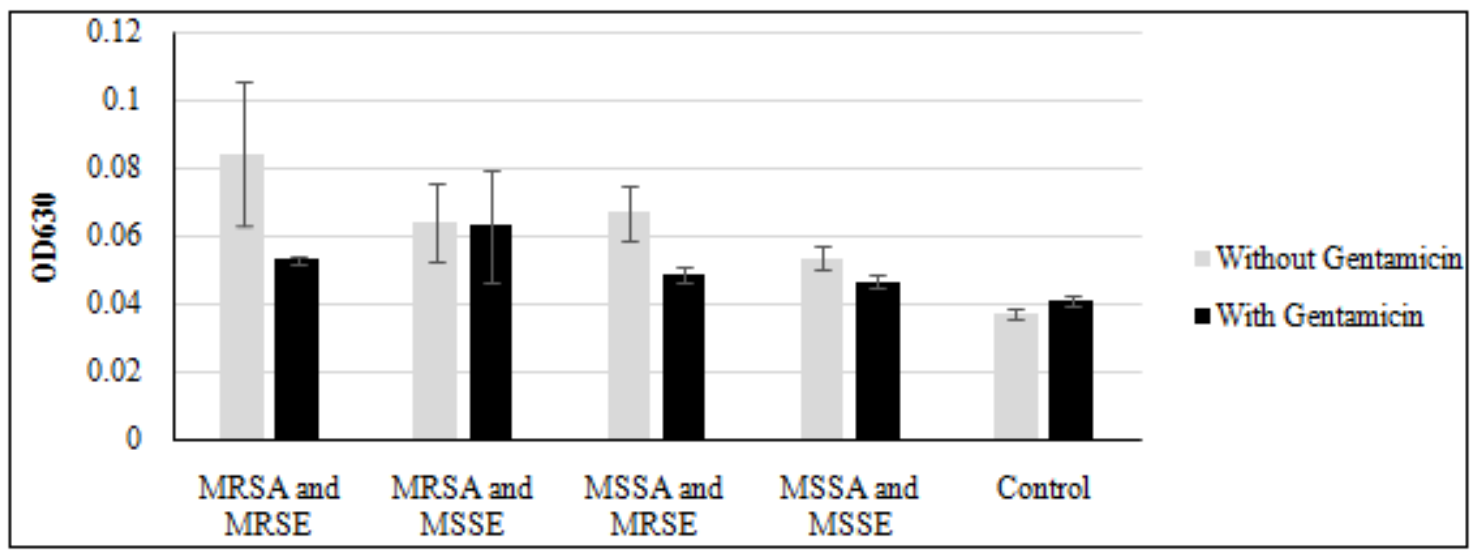

Figure 4: Effect of Gentamicin $(32 \mu \mathrm{g} / \mathrm{ml})$ on Biofilm at $\mathrm{pH} 7$ and $45^{\circ} \mathrm{C}$

In Gentamicin free medium, MRSA and MSSA overnumbered $(\mathrm{P}<0.05)$ MSSE when they incubated at $\mathrm{pH}$. Whereas, when Gentamicin was added, MRSA overnumbered MRSE in addition to numbers of cells is highly reduced post Gentamicin addition (Table 8). Evidently, biofilms formed by all combinations were highly influenced $(\mathrm{P}<0.05)$ by the presence of Genamicin as it is illustrated in Figure 5.

Table 8: Effect of Gentamicin* on Biofilm cell viability at $\mathrm{pH} 6$ and $37^{\circ} \mathrm{C}$

\begin{tabular}{|c|l|l|l|l|}
\hline \multirow{2}{*}{ Species combinations } & \multicolumn{3}{|l|}{ Without Gentamicin $(\times 10$ CFU/ml $)$} & With Gentamicin $(\times 10$ CFU/ml $)$ \\
\cline { 2 - 5 } & S. aureus & S. epidermidis & S. aureus & S. epidermidis \\
\hline MRSA and MRSE & $\mathbf{6 8 2}$ & $\mathbf{8 0 0}$ & $\mathbf{1 3 6}$ & $\mathbf{5 9}$ \\
\hline MRSA and MSSE & $\mathbf{1 1 2}$ & $\mathbf{8 4}$ & Undetectable & Undetectable \\
\hline MSSA and MRSE & $\mathbf{4 6 9}$ & $\mathbf{8 1 2}$ & Undetectable & Undetectable \\
\hline MSSA and MSSE & $\mathbf{1 0 5 6}$ & $\mathbf{3 9 7}$ & Undetectable & Undetectable \\
\hline
\end{tabular}

*Gentamicin was added $32 \mu \mathrm{g} / \mathrm{ml}$ (subMIC) 


\section{International Journal of Science and Research (IJSR) \\ ISSN (Online): 2319-7064}

Index Copernicus Value (2015): 78.96 | Impact Factor (2015): 6.391

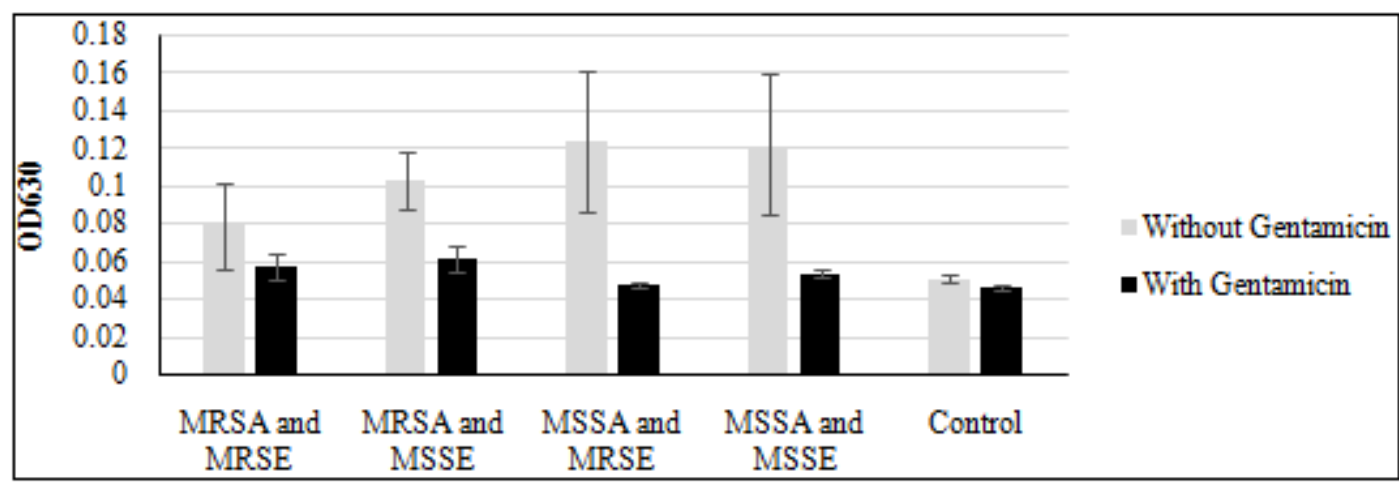

Figure 5: Effect of Gentamicin $(32 \mu \mathrm{g} / \mathrm{ml})$ on Biofilm at $\mathrm{pH} 6$ and $37^{\circ} \mathrm{C}$

Once again, at $\mathrm{pH} 8$, S. epidermidis had a superiority $(\mathrm{P} \leq$ 0.05 ) in biofilm over $S$. aureuswith and without Gentamicin addition (Table 9). However, Gentamicin highly affected (P $\leq 0.05)$ biofilm thickness as shown in Figure 6 and cell numbers (Table 9).

Table 9: Effect of Gentamicin* on Biofilm cell viability at $\mathrm{pH} 8$ and $37^{\circ} \mathrm{C}$

\begin{tabular}{|c|l|l|l|l|}
\hline \multirow{2}{*}{ Species combinations } & \multicolumn{2}{|l|}{ Without Gentamicin $(\times 10$ CFU/ml $)$} & \multicolumn{2}{|c|}{ With Gentamicin $(\times 10$ CFU/ml $)$} \\
\cline { 2 - 5 } & S. aureus & S. epidermidis & S. aureus & S. epidermidis \\
\hline MRSA and MRSE & $\mathbf{6 2 0}$ & $\mathbf{6 9 4}$ & $\mathbf{8 2}$ & $\mathbf{9 2}$ \\
\hline MRSA and MSSE & $\mathbf{3 6 3}$ & $\mathbf{9 6 4}$ & $\mathbf{2 5}$ & $\mathbf{3 9}$ \\
\hline MSSA and MRSE & $\mathbf{6 0 7}$ & $\mathbf{1 0 5 5}$ & $\mathbf{7 7}$ & $\mathbf{1 5 4}$ \\
\hline MSSA and MSSE & $\mathbf{8 0}$ & $\mathbf{1 5 2}$ & $\mathbf{8 0}$ & $\mathbf{1 6 9}$ \\
\hline
\end{tabular}

*Gentamicin was added $32 \mu \mathrm{g} / \mathrm{ml}$ (subMIC)

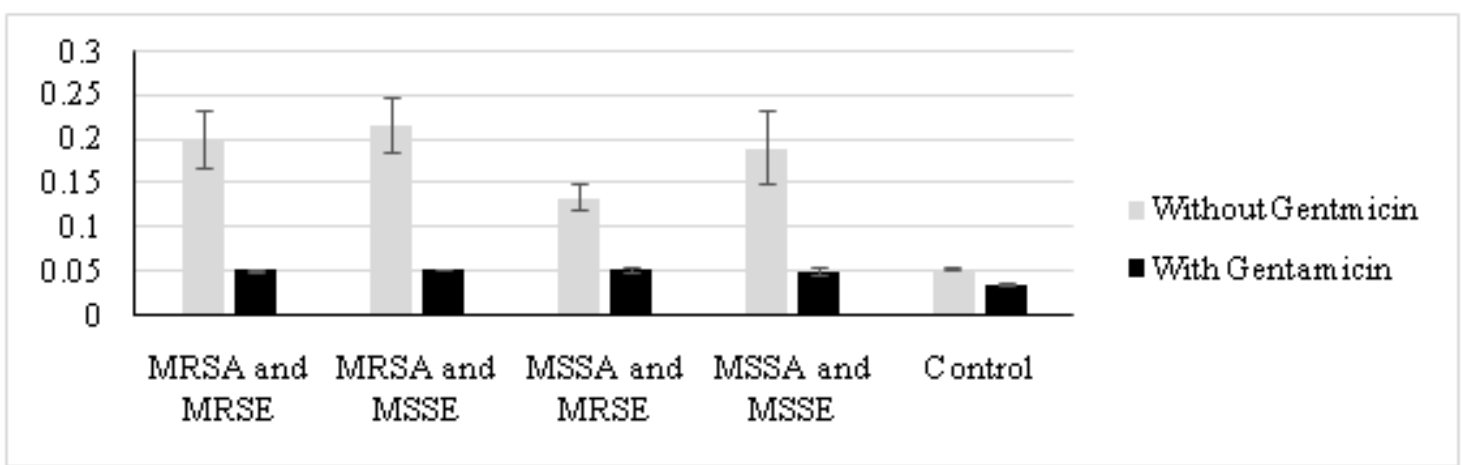

Figure 6: Effect of Gentamicin $(32 \mu \mathrm{g} / \mathrm{ml})$ on Biofilm at $\mathrm{pH} 8$ and $37^{\circ} \mathrm{C}$

When biofilm was starved $(1: 100)$, MRSA was in greater number $(\mathrm{P}<0.05)$ than MRSE in Gentamicin free medium; however, in the presence of Gentamicin, S. epidermidis numbers were more than those of $S$. aureus (Table 10). Gentamicin reduced the biofilm thickness in all species combination (Figure 7).

Table 10: Effect of Gentamicin* on starved** Biofilm cell viability at $\mathrm{pH} 7$ and $37^{\circ} \mathrm{C}$

\begin{tabular}{|c|c|c|c|c|}
\hline \multirow{2}{*}{ Species combinations } & \multicolumn{2}{|c|}{ Without Gentamicin $(\times \mathbf{1 0}$ CFU $/ \mathbf{m l})$} & \multicolumn{2}{|c|}{ With Gentamicin $(\times \mathbf{1 0}$ CFU $/ \mathbf{m l})$} \\
\hline & S. aureus & S. epidermidis & S. aureus & S. epidermidis \\
\hline MRSA and MRSE & 602 & 53 & 197 & 987 \\
\hline MRSA and MSSE & 16 & 32 & 12 & 27 \\
\hline MSSA and MRSE & 488 & 675 & 85 & 189 \\
\hline MSSA and MSSE & 66 & 150 & 570 & 589 \\
\hline
\end{tabular}

*Gentamicin was added $32 \mu \mathrm{g} / \mathrm{ml}$ (subMIC);**Brain Heart Infusion at 1:100 dilution. 
International Journal of Science and Research (IJSR)

ISSN (Online): 2319-7064

Index Copernicus Value (2015): 78.96 | Impact Factor (2015): 6.391

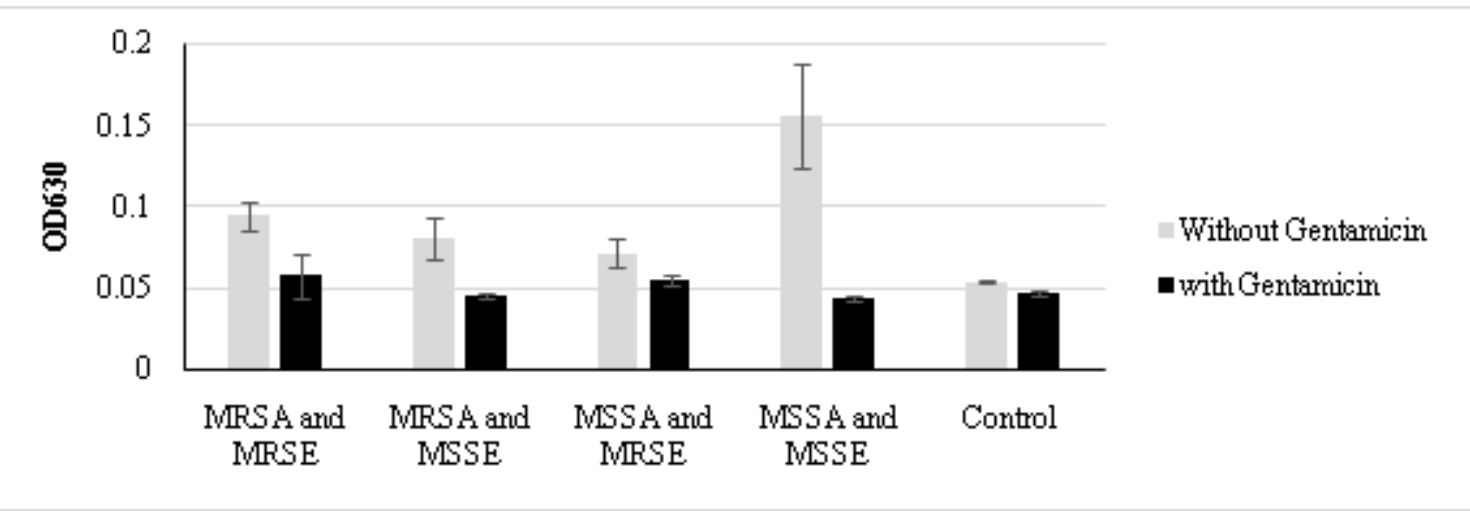

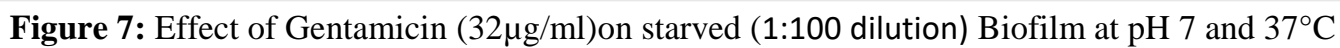

But when biofilm was starved at 1:1000,S. epidermidis exceeded $S$. aureusin all species combinations except for MSSA; which hadtopped $(\mathrm{P}<0.05)$ MRSE in the presence of Gentamicin (Table 11). In regard to biofilm thickness, Gentamicin reduced thickness of all biofilms in exception for MRSA and MRSE (Figure 8)

Table 11: Effect of Gentamicin* on starved** Biofilm cell viability at $\mathrm{pH} 7$ and $37^{\circ} \mathrm{C}$

\begin{tabular}{|c|c|c|c|c|}
\hline \multirow[t]{2}{*}{ Species combinations } & \multicolumn{2}{|c|}{ Without Gentamicin $(\times 10$ CFU/ml $)$} & \multicolumn{2}{|c|}{ With Gentamicin $(\times \mathbf{1 0}$ CFU/ml) } \\
\hline & S. aureus & S. epidermidis & S. aureus & S. epidermidis \\
\hline MRSA and MRSE & 45 & 142 & 674 & 867 \\
\hline MRSA and MSSE & 81 & 183 & 163 & 1336 \\
\hline MSSA and MRSE & 117 & 208 & 135 & 90 \\
\hline MSSA and MSSE & 173 & 1062 & 453 & 847 \\
\hline
\end{tabular}

*Gentamicin was added 32 $\mu \mathrm{g} / \mathrm{ml}$ (subMIC);**Brain Heart Infusion at 1:1000 dilution.

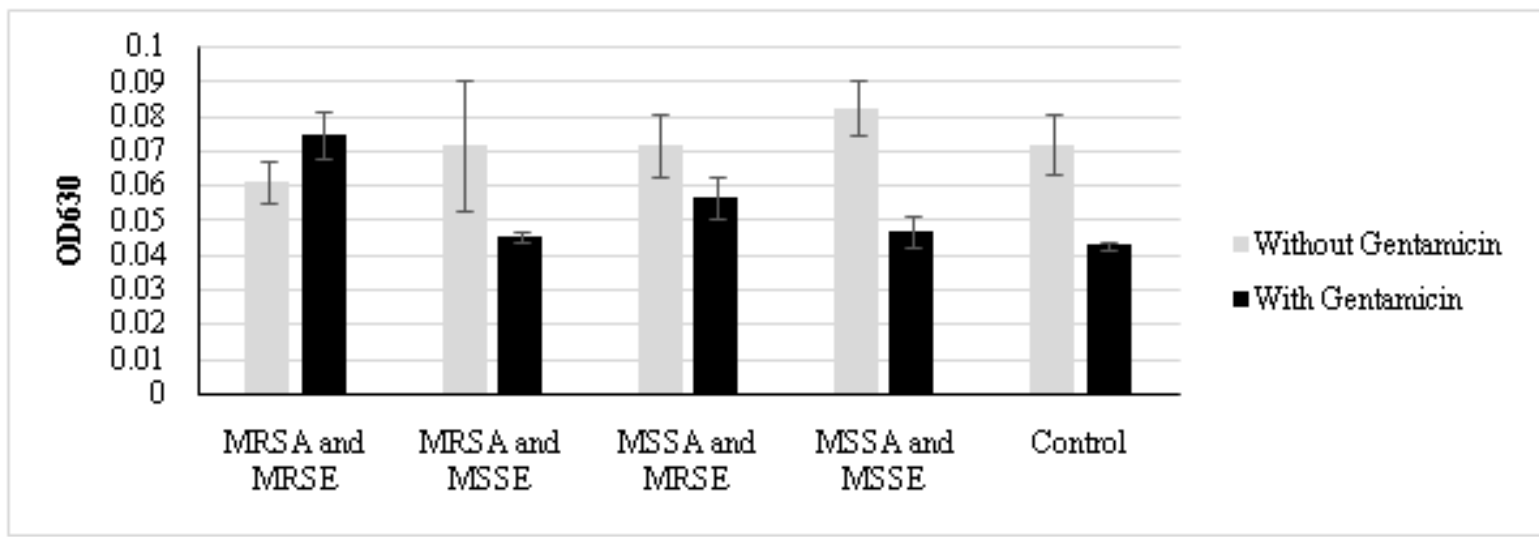

Figure 8: Effect of Gentamicin $(32 \mu \mathrm{g} / \mathrm{ml})$ on starved(1:1000 dilution)Biofilm cell viability at pH 7 and $37^{\circ} \mathrm{C}$

The dominance of S. epidermidis over S.aureus reflects the ability of $S$. epidermidis to adapt and overcome the adverse conditions on the expense of $S$. aureus. Perhaps, it possesses colonizing factors or other determinants enable them to compete successfully other microorganisms which might found in vicinity.

Sato et al., [58]stated that MRSA displayed a lowered surface electronegativity alongside with a shortage in teichoic acids amount. Even though the physicochemical features of such surfaces could hypothetically affect adhesion.

Iwase et al. [59] reported that the serine protease Esp secreted by S.epidermidis have inhibited the biofilm formation of S.aureus as well as nasal colonization. Moreover, purified Esp has the ability to destroy the preexisting $S$. aureus biofilms.Sugimoto et al. [60] demonstrated that Esp degraded certain proteins found in the biofilm matrix and cell wall of $S$. aureus. Additionally Esp developed an ability to degrade colonization factors, such as fibronectin-binding protein A and protein A. Furthermore, Esp selectively degraded many host receptors of $S$. aureus (e.g., vitronectin, fibrinogen, and fibronectin).

Burmolle et al.[61]demonstrated that synergistic increases in biofilm mass in mixed- versus single-species biofilms. However, Macleod and Stickler [62] specifically investigated a mixed culture of Proteus mirabilis and $P$. aeruginosa in catheter biofilms, and they found minimal antagonism between the two species.

In a study achieved byVarposhti et al. [63], Pseudomonas aeruginosa, Acinetobacter baumannii, and Stenotrophomonas maltophilia were investigated togetherand inter-species communication among them, comprising some secreted factors (e.g. proteins, quorumsensing molecules, secondarymetabolites, and

\section{Volume 6 Issue 7, July 2017 www.ijsr.net}




\section{International Journal of Science and Research (IJSR) \\ ISSN (Online): 2319-7064}

Index Copernicus Value (2015): 78.96 | Impact Factor (2015): 6.391

carbohydrates), which affect geneexpression, physicalcontact, the production of antimicrobials, metabolic cooperation and competition, maylead to improved biofilm formation. The precise mechanism ofsynergism among these species is unknown. However, one or more of the interactions stated above may haveoccurred.

Lehman and Donlan [64] stated that the numbers of biofilmassociated $P$. aeruginosa and $P$. mirabilis were not affected by the presence of the other species at the 2-h, 24-h, and 48$\mathrm{h}$ time points. The elimination of $P$. aeruginosa by $72 \mathrm{~h}$ in the two-species catheter reactors, regardless of phage treatment, was likely driven by the high $\mathrm{pH}$ that developed between 48 and $72 \mathrm{~h}$ due to $P$. mirabilis urease activity, as evidenced by $P$. aeruginosa growth inhibition in medium with $\mathrm{pH} 10$. However, the high $\mathrm{pH}$ did not appear to inhibit lytic activities for either the $P$. mirabilis or $P$. aeruginosa phages in our catheter model, suggesting that phage application in indwelling urinary catheters with high $\mathrm{pH}$ conditions might be feasible.

\section{References}

[1] Gill, S.R., Fouts, D.E., Archer,G.L., Mongodin, E.F., DeBoy,R.T.,Ravel,J., Paulsen, I.T., Kolonay, J.F., rinkac,L., Beanan, M.,Dodson,R.J., Daugherty, S.C., Madupu,R., Angiuoli,S.V., Durkin,A.S., Haft, D.H., Vamathevan, J., Khouri, H., Utterback, T., Lee, C., Dimitrov, G., Jiang, L., Qin, H., Weidman, J., Tran, K., Kang, K., Hance, I.R., Nelson, K.E. and Fraser, C.M.(2005). Insights on Evolution of Virulence and Resistance from the Complete Genome Analysis of an Early Methicillin-Resistant Staphylococcus aureus Strain and a Biofilm- Producing Methicillin Resistant Staphylococcus epidermidis Strain. J. Bacteriol. 187:2426- 2438.

[2] Christensen, G.D., Simpson, W.A., Younger, J.J., Baddour, L.M., Barrett, F.F., Melton, D.M. and Beachey, E.H. (1985). Adherence of coagulase negative staphylococci to plastic tissue culture plates: a quantitative model for the adherence of staphylococci to medical devices.J. Clin. Microbiol. 22: 996-1006

[3] Jabra-Rizk, M.A.; T.F. Meiller; C.E. James; and M.E. Shirtliff. 2006. Effect of Farnesol on Staphylococcus aureus Biofilm Formation and Antimicrobial Susceptibility. Antimicrob. Agents Chemother. 50(4):1463-1469.

[4] Holt, J. G., Krieg, N. R.,Sneath, P. H. A.,Staley, J. T. and Williams, S. T.(1994). Bergey's manual of determinative bacteriology. $9^{\text {th }}$ edn. Williams and Wilkins. Baltimore,MD.

[5] Kloos, W.E., and Schleifer, K.H.(1975). Simplified Scheme for Routine Identification of Human Staphylococcus Species. J. Clin. Microbiol.1: 82- 88.

[6] MacFaddin , J.F.(2000). Biochemical Tests for Identification of Medical Bacteria. $3^{\text {rd }}$.ed. Lippinocott Williams \&Wilkins, USA. P.555-565.

[7] Clinical and Laboratory Standards Institute (CLSI) (2015). Performance Standards for Antimicrobial Susceptibility testing, 20th supplement, CLSI document M 100-S23. 29(3). CLSI, Wayne, Pennsylvania, USA.

[8] Arciola, C. R., Baldassarri, L. and Montanaro,
L.(2001). Presence of icaA and icaD Genes and Slime Production Collection of Staphylococcal Strains from Catheter-Associated Infections. J. Clin. Microbiol. 39: 2151- 2156.

[9] Clinical and Laboratory Standards Institute (CLSI) (2016). Performance Standards for Antimicrobial Susceptibility testing, 26th Edition, CLSI document M 02-A12, M07-A10, andM11-A8. CLSI, Wayne, Pennsylvania, USA.

[10] Nakao, R., Ramsted,t. M. , Wai, S.N. and Uhlin, B.E. (2012). Enhanced Biofilm Formation by Escherichia coli LPS Mutants Defective in Hep Biosynthesis. PLoS One. 7(12):e51241.

[11] Atshan, S. S., Lung L.T. T., Ali A. M., Shamsudin M. N., Hamat R. A., Ghaznavi-Rad, E., Seng J. S. C., Sekawi, Z., Karunanidhi A.,GhasemzadehMoghaddam, H., Nathan, J.J., and Pei C.P.(2012). Prevalence of Adhesion and Regulation of BiofilmRelated Genesin Different Clones of Staphylococcus aureus. J. BioMed. Bioec.

[12] Onanuga, A. and Temedie, T.C. (2011).Nasal carriage of multi-drug resistant Staphylococcus aureus in healthy inhabitants of Amassoma in Niger delta region of Nigeria. Afr. Health Sci.11(2):176-81.

[13] Babakir-Mina, M., Othman N. , Najmuldeen, H. H. , Noori, C. K. , Fatah C.F. , Perno, C. and Ciotti, M.(2012). Antibiotic susceptibility of vancomyin and nitrofurantoin in Staphylococcus aureus isolated from burnt patients in Sulaimaniyah, Iraqi Kurdistan . New Micro. 35: 439-446.

[14] Vaez H., Tabaraei A., Moradi A. and Ghaemi E. A. (2011).Evaluation of methicillin resistance Staphylococcus aureus isolated from patients in Golestan province-north of Iran . African J. Microbiol. Res. 5: 432-436.

[15] Eftekhar F. and Mirmohamadi Z. (2009).Evaluation of biofilm production by Staphylococcus epidermidis isolates from nosocomial infections and skin of healthy volunteers . Intern.J. Med. and Med. Sci. 1: 438441.

[16] Diemond-Hernandez, B., Sor zano-Santos, F., Lea os-Miranda, B., rzano Peregrino-Bejarano, L., Miranda-Novales, G. (2010).Production of icaADBC-encoded polysaccharide intercellular adhesin and therapeutic failure in pediatric patients with staphylococcal device-related infections. B.M.C. Infec.Dise.10:68

[17] Gad, G. F. M., El-Feky M.A., El-Rehewy M. S., Amin M., Hassan, Abolella, H. and Abd El-Baky, R.M. (2009). Detection of icaA, icaD genes and biofilm production by Staphylococcus aureus and Staphylococcus epidermidis isolated from urinary tract catheterized patients . J. Infect. Dev. Ctries. 3:342-351.

[18] Adesida,S.A.,Abioye,O.A.,Bamiro,B.S.,Brai,B.I.C. ,Smith,S.I.,Amisu, K.O., Ehichioya, D.U., Ogunsola, F.T. and Coker, A.O. (2007). Associated risk factors and pulsed field gel electrophoresis of nasal isolates of Staphylococcus aureus from medical students in a tertiary hospital in Lagos, Nigeria. Braz. J. Infect. Dis. 11(1): 63-69.

[19] Chopra, S., Kaur, J., Sheevani, Mahajan (2013)

\section{Volume 6 Issue 7, July 2017 www.ijsr.net}




\section{International Journal of Science and Research (IJSR) \\ ISSN (Online): 2319-7064}

Index Copernicus Value (2015): 78.96 | Impact Factor (2015): 6.391

Blood culture isolates in paediatric patients and antimicrobial resistance patterns . I.J.P.D. 8:7-14

[20] Rabelo, M.A., Neto, A.M., da Silva, E.C., de Oliveira, W.L., de Melo F. L., Lopes A.C., Leal N. C. and Macie, M. A.(2013).Phenotypic methods for determination of methicillin resistance in Staphylococcus spp.from health care workers . J. Bras. Patol. Med. Lab. 49: 91-96.

[21] Onanuga, A. and Onalapo, J.A. (2008). Antimicrobial susceptibility of community associated Staphylococcus aureus isolates from healthy women in Zaria. Tropical Journal of Pharmaceutical Research.7(1):929-939.

[22] Al-Geobory, H. A. (2011). Comparative study between Methicillinresistant Staphylococcus aureus (MRSA) and Methicillin sensitive Staphylococcusaureus (MSSA), and detect the antimicrobial effects of some plant extracts on them. M.Sc. thesis. College of Science. Baghdad University.

[23] Pant, J. and Rai, S.K. (2007). Occurrence of Staphyloccous aureus in Hospital Environment and Staffs in Teaching Hospital in Katmandu, Nepal. J. Nepal Assoc. Medi. Lab. Sci.8:72-73.

[24] Boyce, J. M., Cookson, B., Christiansen, K., Hori, S., Vuopio-Varkila, J., Kogagoz , S., Oztop, A. Y., Vanden-Grauls, C. M., Harbarth, S. and Pittet, D.( 2005). Methicillin-resistant Staphylococcus aureus. Lancet. Infect. Dis. 5653- 663.

[25] Fernandes C.J., Fernandes L.A., and Collignon P. (2005). Cefoxitinresistance as a surrogate marker for the detection of methicillin-resistant Staphylococcus aureus. J. Antimicrob. Chemother. 55:506-510.

[26] Swenson, J. M., Tenover, F. C. and Cefoxitin Disk Study Group.(2005). Results of disk diffusion testing with cefoxitin correlate with presence of mecA in Staphylococcus spp. J. Clin. Microbiol. 43:38183823.

[27] Tomasz, A., Nachman, S., and Leaf, H. (1991). Stable classes of phenotypic expression in methicillinresistant clinical isolates of staphylococci. Antimicrob. Agents Chemother. 35:124-129.

[28] Al-Hasani, H. M. (2005). Comparative Study between Methicillin- Resistant Coagulase Positive and Negative Staphylococci. M.Sc. Thesis College of Science, University of Baghdad, Iraq.

[29] Abd-Elateef, A.N. (2008).Comparative Study between Local Isolates of Methicillin Sensitive and Resistance of Staphylococcus epidermidis. M.Sc. thesis college of science, university of Baghdad, Iraq .

[30] Al-Dahbi, A. M. and Al-Mathkhury, H. J. (2013). Distribution of Methicillin Resistant Staphylococcus aureus in Iraqi patients and Healthcare Worker. Iraqi J.Sci. 54: 293-300

[31] Muhammad, H. A. (2013). A comparative study on biofilm forming capacity in Methicillin Resistant Staphylococcus aureus and Methicillin Resistant Staphylococcus epidermidis by using different techniques. M.Sc. Thesis College of Science, University of Baghdad, Iraq.

[32] Japoni, A., Alborzi, A.V., Rasouli, M., Pourabbas, B. (2004). Modified DNA extraction for rapid PCR detection of methicillin resistant Staphylococci. Iran. Biomed. J. 8: 61-5.
[33] Ekrami, A. and Kalantar, E. (2007). Bacterial infections in burn patients at a burn hospital in Iran. Indian J. Med. Res. 126:541-4.

[34] Mehdinejad, M., Frajzade, A. and Jolodar, A. (2008).Study of Methicillin resistance in Staphylococcus aureus and species of coagulase negative Staphylococci isolated from various clinical specimens. Pak. J. Med. Sci. 24: 115-7.

[35] Khorvash, F., Mostafavizadeh, K. and Mobasherizadeh, S. (2008). Frequency of mecA Gene and Borderline Oxacillin Resistant Staphylococcus aureus in Nosocomial Acquired Methicillin Resistance Staphylococcus aureus Infections. Pak. J. Biol. Sci. 11:1282-1285.

[36] Hodle, A.E., Richter, K.P. and Thompson, R.M.(2006). Infec. control practices in US burn units. Mol. Biol. Rep. 27:142-51.

[37] Al-Hasani, H. M. (2011). Comparative Study between Methicillin-Resistant Coagulase Positive and Negative Staphylococci. M.Sc. Thesis College of Science, University of Baghdad, Iraq.

[38] Al-Maliki, A.A.A. (2009). A Study of some Methicillin-Resistant Staphylococci (MRSA) and (MRSE) isolated from Baghdad hospital patients. M.Sc.Thesis. College of Science. AL-Mustansiriya University.

[39] Mehrotra, M.; G. Wang; and W. M. Johnson. (2000). Multiplex PCR for Detection of Genes for Staphylococcus aureus Enterotoxins, Exfoliative Toxins, Toxic Shock Syndrome Toxin 1, and Methicillin Resistance. J. Clin. Microbiol. 38(3):10321035.

[40] Strommenger, B.; C. Kettlitz; G. Werner; and W. Witte. (2003). Multiplex PCR Assay for Simultaneous Detection of Nine Clinically Relevant Antibiotic Resistance Genes in Staphylococcus aureus. J. Clin. Microbiol.41(9):4089-4094

[41] Kurazono, M.; T. Ida; K. Yamada; Y. Hirai; T. Maruyama; E. Shitara; and M. Yonezawa. (2004). In Vitro Activities of ME1036 (CP5609), a Novel Parenteral Carbapenem, against Methicillin-Resistant Staphylococci. Antimicrob. Agents Chemother. 48(8):2831-2837.

[42] Vandenesh, F.; T. Naimi; M.C. Enright; G. Lina; G.R. Nimmo; H. Heffernan; N. Liassine; M. Bes; T. Greenland; M.E. Reverdy; and J. Etienne. (2003). Community-Acquired Methicillin- Resistant Staphylococcus aureus Carrying Panton-Valentine Leukocidin Genes: Worldwide Emergence. Emerg. Infect. Dis. 9(8):978-984.

[43] Chung, H.; H. Jeon; H. Sung; M. Kim; and S. Hong.(2008). Epidemiological Characteristics of Methicillin-Resistant Staphylococcus aureus Isolates from Children with Eczematous Atopic Dermatitis Lesions. J. Clin. Microbiol.46(3):991-995.

[44] York, M.K.; L. Gibbs; F. Chehab; and G.F. Brooks. (1996). Comparison of PCR Detection of mecA with Standard Susceptibility Testing Methods To Determine Methicillin Resistance in CoagulaseNegative Staphylococci. J. Clin. Microbiol. 34(2):249253.

[45] Brooks, G.F.; K.C. Carroll; J.S. Butel; and S.A. Morse. (2007).Jawetz, Melnick and Adelbergs 


\section{International Journal of Science and Research (IJSR) \\ ISSN (Online): 2319-7064 \\ Index Copernicus Value (2015): 78.96 | Impact Factor (2015): 6.391}

Medical Microbiology. 24 ${ }^{\text {th }}$.ed. The McGraw- Hill Companies, Inc., New York.P.224-232.

[46] Mack, D.; A. Sabottke; S. Dobinsky; H. Rohde; M.A. Horstkotte; and J.K.-M. Knobloch. (2002). Differential Expression of Methicillin Resistance by Different Biofilm-Negative Staphylococcus epidermidis Transposon Mutant Classes. Antimicrob. Agents Chemother. 46(1):178-183.

[47] Jain, A.; J. Agarwal; and S. Bansal. (2004). Prevalence of methicillin- resistant, coagulasenegative staphylococci in neonatal intensive care units: findings from a tertiary care hospital in India. J.Med.Microbiol. 53:941-944.

[48] Guggenheima, M., Zbinden, R., Handschin, A., Gohritz, A., Altintas ,M. and Giovanoli, P.(2009). Changes in bacterial isolates from burn wounds and their antibiograms: A 20-year study (1986-2005). Burns.35: 553-560.

[49] Skov, R., Smyth, R., Clausen, M., Larsen, A.R., Frimodt-Mller, N. and Olsson-Liljequist, B. (2003). Evaluation of a cefoxitin $30 \mu \mathrm{g}$ disc on IsoSensitest agar for detection of methicillin-resistant Staphylococcus aureus. J. Antimicrob. Chemother. 52:204-7.

[50] Al-Dahbi, A.H. (2013).Comparative study between Methicillin Resistant Staphylococcus aureus (MRSA) $a g r+$ isolates and MRSA $a g r$ - isolates. M.Sc. thesis. College of Science, University of Baghdad, Iraq.

[51] Gad, G. F. M., Aziz, A. A.A. and Ibrahem, R. A. (2012). In-vitro adhesion of Staphylococcus spp. To certain orthopedic biomaterials and expression of adhesion genes. J. Appl. Phar. Sci. 02:145-149

[52] Līduma, I., Tračevska T., Bērs U. and Žileviča A. (2012). Phenotypic and genetic analysis of Biofilm Formation by Staphylococcus epidermidis. Medicina. (Kaunas) 48:305-9

[53] Oliveira, A. and Cunha, M.L.(2010). Comparison of methods for the detection of biofilm production in coagulase-negative staphylococci . Oliveira and Cunha BMC Res. Notes.3:260.

[54] Fey, P. D., Salid-Salim, B., Hinrich, S. H., Boxrud, D. J., Davis,C. C., Kreiwirth, B. N. and Schlievert, P. M. (2002). Comparative molecular analysis of community or hospital-Acquired Methicillin-Resistant Staphylococcus aureus. Antimicrob. Agents Chemother. 47(1):196-203.

[55] Jain, A., Agarwal, A. and Verma, R.K. (2008). Cefoxitin disc diffusion test for detection of meticillinresistant staphylococci. J. Med. Microbiol. 57:957-61.

[56] Bockstael, K. and Van Aerschot, A. (2009). Antimicrobial resistance in bacteria. Cent. Eur. J. Med. 4(2):141-155.

[57] Rachakonda, S. and Cartee, L. (2004). Challenges in antimicrobial drug discovery and the potential of nucleoside antibiotics, Curr. Med. Chem. 11: 775-793.

[58] Sato, M., Tsuchiya, H., and Yamaguchi, R. (1994). Coaggregation of methicillin-sensitive and-resistant Staphylococcus aureus with oral microorganisms. Jpn. J. Oral Biol., 36: 520-525.

[59] Iwase T, Uehara Y, Shinji H, Tajima A, Seo H, Takada K, Agata T, and Mizunoe Y. 2010. Staphylococcus epidermidis Esp inhibits
Staphylococcus aureus biofilm formation and nasal colonization.Nature. 465: 346-349

[60] Sugimoto, S., Iwamoto, T., Takada, K., Okuda, K.,Tajima, A., Iwase, T., and Mizonue, Y. 2013. Staphylococcus epidermidis Esp Degrades Specific Proteins Associated with Staphylococcus aureus Biofilm Formation and Host-Pathogen Interaction. J. Bacteriol. 195: 1645-1655

[61] 61.Burmolle M, Webb JS, Rao D, Hansen LH, Sørensen SJ, Kjelleberg S. 2006. nhaEnced biofilm formation and increased resistance to antimicrobial agents and bacterial invasion are caused by synergistic interactions in ultispecies biofilms. Appl Environ Microbiol72:3916-3923

[62] Macleod SM, Stickler DJ. 2007. Species interactions in mixedcommunity crystalline biofilms on urinary catheters. J Med Microbiol56:1549-1557.

[63] Varposhti, M., Entezari, F., and Feizabadi, M. 2014. Synergistic interactions in mixed-species biofilms of pathogenic bacteria from the respiratory tract. Revista da SociedadeBrasileira de Medicina Tropical 47(5):649-652.

[64] Lehman SM, Donlan RM. 2015. Bacteriophagemediated control of a twospeciesbiofilm formed by microorganisms causing catheter-associated urinary tract infections in an in vitro urinary catheter model. Antimicrob AgentsChemother 59:1127-1137 